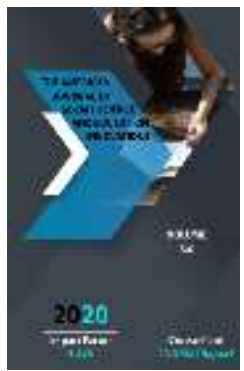

Journal Website: http://usajournalshub.c om/index,php/tajssei

Copyright: Original content from this work may be used under the terms of the creative commons attributes 4.0 licence.

\section{Multimedia Technologies And Fundamentals Of Use}

\section{Usmonov}

Senior Teachers Of Jizzakh State Pedagogical Institute, Uzbekistan

H. Shukurova

Senior Teachers Of Jizzakh State Pedagogical Institute, Uzbekistan

B. Suvonqulov

Senior Teachers Of Jizzakh State Pedagogical Institute, Uzbekistan

\title{
ABSTRACT
}

This article provides the basics of creating and using an interactive electronic training course based on multimedia technologies. The article emphasizes the need to use interactive e-learning courses, how to create interactive e-learning courses and procedures in the learning process, and lecture sessions.

\section{KEYWORDS}

Multimedia, technology, interactive, e-learning, educational, multimedia technologies, information technology.

\section{INTRODUCTION}

In the application of information technology (IT) in the educational process, the search for forms and methods that improve the content of teaching plays an important role. 


\section{MATERIALS AND METHODS}

In the application of information technology in the educational process, special attention is paid to lectures, and this teaching method is one of the most important forms of teaching in higher education. Improving the theoretical and ideological aspects of lectures will further increase its importance in the educational process. Many educators have noted that the development of lecture classes leads to an increase in the quality of teaching. The purpose of the lecture is to equip students with teaching materials to ensure that they can work independently with practical, laboratory work and educational literature.

\section{RESULT AND DISCUSSION}

In order for students to master lectures, they are required to have a certain level of knowledge, will and attention. Therefore, it is very effective to ensure that students work with teachers in the conduct of lectures. At the same time, it is necessary to pay special attention and create conditions for independent work of students. The more students ponder the topic, the more they will understand and remember it. Understanding and remembering is one of the best and most solid ways to gain knowledge.

Independent practice leads to the development of psychological processes in students and then prepares them to think on a large scale, to analyze events and facts so that they can understand the topic. It should be noted that the use of didactic elements on the topics in the course of lectures gives good results. Therefore, the preparation for lectures is a separate issue. This allows the use of modern tools in the preparation of lectures, the introduction of components such as visual, auditory, comparative, visual presentation of teaching materials on the topic, which increases the effectiveness of lectures.
There are opinions in many literature in the field of pedagogy about the shortcomings of traditional teaching methods. Including, V. I. Onishenko and M. N. According to Gendins, at present, the lecture is a generalizing process, which, on the one hand, provides the teacher with information, on the other hand, it represents the process of student admission $[3,4]$.

When reading a lecture, the teacher can describe the given material in different forms (speech level, low or high, repetition, additional demonstration). Second, the teacher may not know exactly when the need arose. This may be due to the fact that students do not actively participate in certain parts of the lecture sessions. This, in turn, leads to a lack of mastery of the material from lesson to lesson. In this sense, the introduction of multimedia technologies in the educational process in the form of electronic copies of educational materials creates a wide range of opportunities for students and teachers. For each subject to be taught, its content is usually chosen according to a set goal. Appropriate methods, teaching aids and finally the appropriate form of teaching are selected to master it.

Ensuring continuity in education depends on the integral relationships between its components, such as purpose, content, method, tool, form, called the methodological system. In this case, can the disciplines that are now designed to teach science meet the requirements of the time? the question arises. There is always a problem of content and methods in education, and these problems are inextricably linked. Problems in teaching methods are related to the question "who do we teach?", Which stems from the fact that the development of teaching methods depends on its content. These two problems are contradictory and complementary. 
Depending on the psychological preparation of students, the level of thinking or the level of mastery of the acquired knowledge, appropriate content and methods are selected for each stage of education. There are logics and ways to describe the specific content of each stage.

The purpose of the method is to create a new subject (subject) in this subject and to ensure the mastery of this subject. Such disciplines meet all the needs of the student, based on the principle of "first read, then read to teach" based on the requirements of advanced pedagogical technologies, the level of mastery of the material, the definition of control tasks based on simple-complex rules of theoretical and practical knowledge. features such as individual and stratified approaches should be taken into account.

In order to properly solve the tasks and problems of the methodology, it is necessary to find solutions to two interrelated problems, including the creation of concepts for teaching science and how to interpret the content of science. Concepts of teaching science were created in the 8os. Now the goals of teaching science are changing. In this regard, it is worthwhile to consider these concepts. The problems and content of interpreting the content of sciences is to ensure that the reader's attention, interest, and connection between theory and practice. It is obvious that in the traditional methodology, taking into account the development of the student's personality, he does not pay attention to the development of knowledge into skills, and from there to skills. The teacher tries to give the student as much information as possible about the subject of the science being studied. At the same time, the teacher does not always follow a three-stage model of knowledge, such as collecting information, selecting and processing it, and applying the learned (taught) information. The next step is to move the student's cognitive activity (acquired knowledge) to a new level, that is, the process of activation of cognitive activity. Only then does knowledge become skill, and skill becomes skill.

Activation of student learning is based on a number of principles:

- Interest in the study of science;

- Application of problem methods;

- Use of information and pedagogical technologies;

- Based on basic phrases;

- Organization of independent work;

- Organization of general and individual work;

- Use of visual and technical aids;

- Linking the content of education to life;

- Establishing the connection of disciplines, etc.

The main tasks that a teacher should follow in this process are:

- To instill in the student a sense of selfconfidence;

- Provide the necessary support to the student in a timely manner.

In this regard, the subject should be prepared taking into account all the requirements as a means of reflecting the content and methods of education. The basics of the organization of the teaching process on the basis of information technology are radically different from the traditional teaching method, which is for teachers and students:

- Presentation of educational materials in the form of images;

- Organization of differential and individual learning process;

- Assessment of the learning process, feedback;

- Self-monitoring and correction; 
- Demonstration of the studied disciplines and their dynamic process;

- Use of computer and information technologies such as animation, graphics, animation, sound in science subjects;

- Development of strategic skills for students to master the subject;

- Creating new conditions for students to work independently;

- Use of distance learning system as educational literature;

- Creates opportunities in the education system, such as savings in teaching and laboratory work.

Research in this area shows that the introduction of modern information technologies in the education system, the targeted use of which leads to increased efficiency of the educational process.

As we have repeatedly mentioned above, one of the important achievements of multimedia technologies has been the creation of software tools that allow the use of multimedia components. The role of these software tools is significant, especially in the organization of practical and laboratory work of the educational process. The use of multimedia in the organization of practical and laboratory classes of the educational process requires the development of new forms and methods. Science teachers, in collaboration with computer experts, create a computergenerated simulation model of the laboratory, practical work on the topic. This type of laboratory work is called s.

Interactive e-learning courses are educational and laboratory work aimed at strengthening the theoretical knowledge of students in a particular area on the basis of multimedia technologies.

The purpose of creating interactive e-learning courses is to establish the broad use of multimedia technologies for practical and laboratory work. In addition, the creation of interactive e-learning courses ensures the implementation of laboratory work in the educational process on the basis of modern pedagogical and multimedia technologies. In addition, the creation of interactive electronic courses allows you to perform work that can not be carried out in the laboratory (toxic substances, lack of materials) and perform work based on them in an environmentally friendly environment. The use of interactive elearning courses in practical and laboratory work ensures the effectiveness of the educational process. From the interactive elearning courses of computer-generated laboratory work, students have the opportunity to see, repeat, discuss at a time convenient and necessary for them. This leads to an increase in the quality of their mastery. Another important aspect is the saving of learning materials when using interactive ecourses. This is because students who take interactive e-learning courses on a computer are ready to use the materials used in the laboratory (reactive and similar) in the required amount without wasting them. Theoretical, practical and psychological preparation of students for independent work plays an important role in increasing the effectiveness of teaching.

We know that in the work plan of educational institutions for the independent work of students is allocated at least an hour of lectures. How to effectively use the hours allocated for this independent work and in what form, how to organize it? pertinent questions arise.

To find an answer to this question, it is necessary to constantly improve the learning process. In our opinion, the organization of independent working hours of students using computer-multimedia technologies is very 
effective. In solving these problems, as mentioned above, the publication of training materials in electronic form is very useful. During the hours allocated for independent work in computer classes, students should be able to practice on the basis of modern computer-multimedia technologies, and in these classes there should be conditions for them to study and practice the subjects they need, laboratory topics from the computer. In this way, the organization of independent hours is convenient for students and allows them to study subjects when needed. One of the necessary conditions for this is the publication of training materials in electronic form. If the teaching materials are organized on the basis of multimedia, then the rate of mastery of students in the process of independent work will be higher.

\section{CONCLUSION}

In short, in the course of the lesson, the theoretical knowledge provided to students in electronic form is combined with practice, thereby creating problem theories, solving problems together with students, developing their independent thinking skills, helping them to understand the essence of the topic. It is important to create multimedia electronic textbooks based on information and pedagogical technologies to organize this problem-based learning and independent work of students.

\section{REFERENCES}

1. Gulomov S.S. and others. Information Systems and Technologies: A Textbook for University Students / Academician S.S. Under the general editorship of Gulyamov. - T .: «Sharq», 2000.- 529 p.

2. Kholmatov T.X., Taylaqov N.I., Nazarov U.A. Informatics. Textbook for higher education institutions. $-T \quad . \quad$ National encyclopedia of Uzbekistan, 2003.- 254p
3. Jo'raev R.H., Taylaqov N.I. Informed learning environment - a tool to increase the effectiveness of teaching education. 2004.- №3. -p. 3-7. 